\title{
PROBLEMATIKA PENDIDIKAN AGAMA ISLAM
}

\author{
Bach. Yunof Candra \\ (bach3candra@gmail.com) \\ Dosen Sekolah Tinggi Ilmu Tarbiyah (STIT) Islamic Village Tangerang
}

\begin{abstract}
Abstrak: Permasalahan dan tantangan yang ada dalam Pendidikan Agama Islam baik dalam pembelajarannya maupun dalam penerapannya multidimensi. Segala sesuatu pasti memiliki problematika yang menjadi permasalahan dan tantangan yang harus dihadapi dan dicari solusinya, terutama dalam pendidikan. Banyak sekali problematika dalam pendidikan yang masih harus diselesaikan. Penulis ingin mengkaji secara khusus tentang problematika yang menjadi masalah dan tantangan dalam Pendidikan Agama Islam. Sudah banyak penelitian tentang problematika Pendidikan Agama Islam, tetapi masih terfokus hanya kepada para pendidik dan menejemen sekolah. Padahal permasalahan Pendidikan Agama Islam bukan hanya ada dalam sebuah institusi pendidikan saja tetapi merupakan permasalahan bagi seluruh elemen masyarakat termasuk keluarga. Dalam kajian ini penulis ingin membahas dan mengkaji tentang problematika Pendidikan Agama Islam yang ditinjau dari ruang lingkup pendidikan yaitu sekolah, keluarga dan masyarakat. Penelitian ini menggunakan metode kualitatif, berdasarkan studi kepustakaan. Semoga tulisan ini bermanfaat dan bisa memberikan solusi bagi permasalahan-permasalahan yang menjadi tantangan-tantangan dalam Pendidikan Agama Islam baik sebagai sebuah disiplin ilmu, institusi ataupun jalan hidup dalam kehidupan setiap manusia, karena agama adalah budaya Tuhan.
\end{abstract}

Kata kunci: Pendidikan, Problematika PAI

\section{A. Pendahuluan}

Pendidikan merupakan salah satu cara untuk mengembangkan potensi diri seseorang juga pribadinya, dengan pribadi dan potensi yang baik maka seseorang bisa memberi manfaat kepada kehidupan yang berada disekitarnya, seperti yang di sampaikan Rasulullah SAW bahwa sebaik- baiknya manusia adalah yang bermanfaat bagi manusia yang lain. Lingkungan yang memiliki masyarakat terdidik akan berkembang dengan baik dan akan memiliki kehidupan yang baik juga. Kegiatan mendidik bukan hanya peran dunia pendidikan atau institusi pendidikan saja tetapi disetiap tempat pada elemen masyarakat dimanapun juga harus melakukan kegiatan mendidik, karena mendidik adalah tugas setiap manusia bukan hanya tugas tenaga pendidik saja, hal ini diingatkan oleh Allah SWT didalam kitabnya Al- Quran surat Al-'Asr ayat ketiga "saling menasehatilah dalam kebenaran dan saling menasehatilah dalam kesabaran”. 
ISTIGHNA, Vol. 1, No 1, Januari 2018 P-ISSN 1979-2824

Homepage: http://e-journal.stit-islamic-village.ac.id/index.php/istighna

Bach. Yunof Candra Problematika Pendidikan Agama Islam

Sebagai bagian dari masyarakat yang bernaung dibawah pemerintahan Negara Kesatuan Republik Indonesia, maka setiap individu masyarakat haruslah peduli, memberikan perhatian dan mengambil peran untuk terwujudnya tujuan pendidikan nasional yang tertuang dalam UU no. 20 tahun 2003 (sisdiknas. Pasal 3) yang isinya: "Pendidikan nasional berfungsi mengembangkan kemampuan dan membentuk watak serta peradaban bangsa yang bermartabat dalam rangka mencerdaskan kehidupan bangsa. Bertujuan untuk berkembangnya potensi peserta didik agar menjadi manusia yang beriman dan bertakwa kepada tuhan yang maha esa, berakhlak mulia, sehat, berilmu, cakap, kreatif, mandiri, dan menjadi warga negara yang demokratis serta bertanggung jawab". 274

Pendidikan Agama Islam selain sebagai sebuah disiplin ilmu dalam bidang pendidikan juga merupakan peran bagi tercapainya tujauan pendidikan itu sendiri. Karena penekanan Pendidikan Agama Islam bukan hanya pada internalisasi nilainilai teori saja tetapi mencangkup tatanan aplikatif yang lebih berpengaruh terhadap interaksi sosial. Individu yang berkecimpung didalam Pendidikan Agama Islam pun tidak kalah penting perannya dalam mewujudkan tujuan pendidikan Nasional. Mereka adalah para pemberi kabar gembira dan para pemberi peringatan, mereka adalah agen-agen pemerintah dalam mewujudkan tujuan pendidikan khusunya yang berkaitan dengan pembentukan watak yang menjadikan manusia beriman, bertakwa, berakhlak mulia, demokratis dan bertanggung jawab. Para pendidik agama Islam harus mewarnai hidup dan kehidupan ini dengan nilai- nilai ilahi, nilai-nilai tuhan, nilai-nilai sang pencipta alam semesta, baik didalam kehidupannya ataupun kehidupan orang-orang disekitarnya, baik dilingkungan sekolah, keluarga ataupun masyarakat.

\section{B. Pendidikan}

Pendidikan merupakan upaya yang dapat mempercepat pengembangan potensi manusia untuk mampu mengemban tugas yang dibebankan kepadanya, karena hanya manusia yang dapat dididik dan mendidik. Pendidikan dapat mempengaruhi perkembangan fisik, mental, emosional, moral, serta keimanan dan

\footnotetext{
${ }^{274}$ Mulyasa, Standar Kompetensi dan Sertifikasi Guru, (Bandung: Rosada, 2009), h. 4.
} 
ISTIGHNA, Vol. 1, No 1, Januari 2018 P-ISSN 1979-2824

Homepage: http://e-journal.stit-islamic-village.ac.id/index.php/istighna

Bach. Yunof Candra Problematika Pendidikan Agama Islam

ketakwaan manusia. ${ }^{275}$ Dalam dictonary of education, pendidikan merupakan: ${ }^{276}$

1. Proses dimana seseorang mengembangkan kemampuan, sikap dan bentukbentuk tingkah laku lainnya dalam masyarakat dimana dia hidup.

2 Proses sosial dimana orang dihadapkan pada pengaruh lingkungan yang terpilih dan terkontrol (khususnya yang datang dari sekolah), sehingga mereka dapat memperoleh dan mengalami perkembangan kemampuan sosial dan kemampuan individual yang optimum.

Dari pokok pikiran di atas, pendidikan menyangkut, ${ }^{277}$

1. Adanya proses aktivitas dalam pokok pikiran nomor satu ditekankan adanya kekuatan pertama dari pihak individu yang memiliki potensi untuk berkembang yang berbeda dengan insting pada binatang yang pada perkembngannya tidak sepesat dan setinggi yang dialami manusia. Dengan perkataan lain pokok pikiran nomor satu menekankan adanya potensi individu untuk berkembang sebagai reaksi adanya rangsangan intervensi dari dunia di luar individu yang disebut dengan pendidikan.

2. Proses tersebut datang dari dua belah pihak yaitu individu yang memiliki potensi untuk berkembang dan dari pihak luar individu yang memiliki potensi untuk mempengaruhi perkembangan individu secara interaktif. Dalam pokok pikiran nomor dua lebih ditekankan pada luar individu yang memiliki peran dalam perkembangan tersebut, sebab setiap individu tidak akan berkembang lebih jauh dari lingkungan atau luar individu dimana individu tersebut hidup. Pengaruh dari luar terhadap individu sangat intensif, bervariasi dan jauh melampaui batas tak terhingga, pengaruh dari luar terhadap binatang bukan tidak ada tetapi terbatas sampai ambang kemampuan insting yang dimiliki binatang.

3. Proses tersebut memiliki intensitas yang sama kuatnya, baik yang datang dari individu (potensi) maupun yang datang dari luar individu lingkungan (environment). Pendidikan yang diwakili oleh proses belajar

${ }^{275}$ Udin Syaefudin Sa'ud dan Abin Syamsuddin Makmun, Perencanaan Pendidikan, (Bandung: Rosada, 2009), h. 6.

${ }^{276}$ Ibid. h. 6

${ }^{277}$ Ibid. h. 7 
ISTIGHNA, Vol. 1, No 1, Januari 2018 P-ISSN 1979-2824

Homepage: http://e-journal.stit-islamic-village.ac.id/index.php/istighna

Bach. Yunof Candra Problematika Pendidikan Agama Islam

meningkatkan intensitas dari kedua belah pihak dengan harapan tujuan pendidikan dapat dicapai secara wajar, intensif dan memuaskan.

Dengan demikian, pendidikan dapat dinyatakan sebagai suatu sistem dengan komponen yang saling berhubungan dan mempengaruhi minimal sebagai berikut $^{278}$ :

1. Individu peserta didik yang memiliki potensi dan kemauan untuk berkembang dan dikembangkan semaksimal mungkin.

2. Individu peserta didik yang mewakili unsur upaya sengaja, terencana, efektif, efisien, produktif, dan kreatif.

3. Hubungan antara pendidik dan peserta didik yang dapat dinyatakan sebagai situasi pendidikan yang menjadi landasan tempat berpijak, tindakan yang dapat digolongkan sebagai tindakan pendidikan.

4. Struktur sosiokultural yang mewakili lingkungan (environment) di antara kenyataan berupa norma yang bersumber dari alam, budaya danreligi.

5. Tujuan yang disepakati bersama yang mengejawantah karena hubungan antara pendidik dan peserta didik dan tidak bertentangan dengan tuntutan normatif sosiokultural dimana pendidikan tersebut tumbuh dan berkembang.

Menurut Iman Al-Baidhowi pendidikan adalah menyampaikan sesuatu pada kesempurnaannya sedikit demi sedikit. ${ }^{279}$ Sedangkan menurut Ar-Rhoghib AlAshfahani pendidikan adalah membentuk sesuatu sedikit demi dsedikit sampai batas kesempurnaan. ${ }^{280}$ Usatadz 'Abdurrahman Al-Bani menyimpulkan dari beberapa definisi bahasa tentang pendidikan, bahwa pendidikan memiliki beberapa unsur: ${ }^{281}$

1. Menjaga fitrah dan memeliharanya.

2. Menumbuhkan setiap kemampuan dan mempersiapkannya

3. Mengarahkan fitrah dan kemampuan yang telah dimiliki agar sesuai dengan kemanfaatannya.

${ }^{278}$ Ibid. h. 7

${ }^{279}$ Abdurrahman An-nahlawi, Usul At-tarbiyyah Al-islamiyyah Wa Asalibaha Fil Bait Wal Madrosah Wal Mujtama', Darul Fikri, Damaskus, h.13

${ }^{280}$ Ibid.

${ }^{281}$ Ibid. 
ISTIGHNA, Vol. 1, No 1, Januari 2018 P-ISSN 1979-2824

Homepage: http://e-journal.stit-islamic-village.ac.id/index.php/istighna

Bach. Yunof Candra Problematika Pendidikan Agama Islam

4. Beproses dalam mencapai semuanya

Kemudian Ustadz 'Abdurrahman Al-bani juga menyimpulkan beberapa nilai penting yang terdapat dalam pendidikan: ${ }^{282}$

1. Pendidikan adalah proses yang memiliki tujuan.

2. Pendidik yang hakiki adalah Allah SWT.

3. Pendidikan harus memiliki proses yang jelas.

4. Mendidik dan dididik adalah fitra setiap manusia.

Pendidikan adalah usaha sadar dan sistematis yang dilakukan tidak hanya untuk memanusiakan manusia tetapi juga agar manusia menyadari posisinya sebagai khalifatullah fil ardhi, yang pada gilirannya akan semakin meningkatkan dirinya untuk menjadi manusia yang bertakwa, beriman, berilmu, dan beramal soleh. Didalam Islam manusia yang beriman, berilmu, dan beramal soleh memang memiliki derajat yang tinggi. Dalam konteks ini juga dalam agama Islam dikenal sebuah istilah ilmu yang amaliah dan amal yang ilmiyyah.

Upaya untuk meningkatkan kualitas pendidikan di Indonesia masih terus dilakukan. Dunia pendidikan adalah sebuah mega proyek bersama bagi anak-anak bangsa yang sedang giat-giatnya membangun agar bermartabat dan tidak ketinggalan dari bangsa-bangsa lain di dunia.

\section{Terminologi Agama}

Agama adalah keyakinan akan adanya dzat yang ghaib dan luhur, yang dzat itu mempunyai perasaan-perasaan dan pilihan, serta mempunyai pelaksanaan dan pengaturan terhadap berbagai hal yang diingini manusia, dan keyakinan bahwa seseorang itu memang diutus (diperintah) untuk bermunajat kepada dzat yang tinggi itu baik secara suka rela atau terpaksa, dengan segala kerendahan dan ketundukan. ${ }^{283}$ Dengan bahasa yang lebih singkat, agama adalah beriman kepada dzat yang mempunyai sifat ketuhanan, yang terwujud dalam bentuk ketaatan dan peribadatan. Ini adalah pengertian tentang agama, jika dilihat dari sisi kejiwaan dalam arti beragama. Namun bila dilihat sebagai sebuah kebenaran yang muncul, maka agama adalah merupakan sekumpulan perundang-undangan teoritis yang

282 Ibid.

${ }^{283}$ Yusuf Al-Qordhowi, Sistem Pengetahuan Islam, Restu Ilahi, Jakarta, 2004, h. 1 
ISTIGHNA, Vol. 1, No 1, Januari 2018 P-ISSN 1979-2824

Homepage: http://e-journal.stit-islamic-village.ac.id/index.php/istighna

Bach. Yunof Candra Problematika Pendidikan Agama Islam

memberikan batasan-batasan tentang sifat ketuhanan ilahiyyah, dan sekumpulan ketntuan-ketentuan praktis yang melukiskan cara-cara peribadatan kepadanya ${ }^{284}$.

Menurut Doktor Muhammad Abdullah Addaraz dalam bukunya "AlQayyim (Ad-Din)", agama terbagi menjadi dua, agama yang benar dan agama yang rusak. Definisi ini juga memasukan pula agama yang mengajarkan kesyirikan dan keberhalaan, karena Al-Quran sendiri juga menamai yang demikian itu sebagai sebuah agama, sebagaimana firman Allah dalm surat AlKafirun ayat keenam "bagimu agamamu, bagiku agamaku”. Dan juga firman Allah dalam surat Ali Imran ayat kedelapan puluh lima "siapa yang menjadikan selain Islam sebagai agama, maka sekali-kali tidak akan diterima (agama itu) dari padanya" 285 .

Ulama-ulama Islam juga telah memberikan definisi tentang agama dengan peraturan ketuhanan yang dapat menuntun orang yang mempunyai akal sehat, dengan segala pilihan (kebebasan) yang dimilikinya, kepada sesuatu yang dapat membawa kebaikan dalam kehidupan dunia ini dan keselamatan akhirat kelak ${ }^{286}$.

Menurut Abu Al-A'la Al-Maududi agama adalah pereaturan kehidupan yang sempurna dan menyeluruh untuk semua segi baik keyakinan, pemikiran, akhlak ataupun amal perbuatan ${ }^{287}$.

Kebutuhan manusia terhadap agama bukanlah sekedar kebutuhan tambahan atau hanya sebagai kebutuhan pelengkap saja, tetapi agama adalah kebutuhan pokok dan asasi bagi setiap manusia. Kebutuhan manusia yang menggelora akan agama, diawali dengan kebutuhannya yang menggelora untuk memahami diri sendiri, memahami eksistensi yang ada di sekelilingnya. Kebutuhan manusia terhadap agama didasari oleh kebutuhan manusia yang menggelora untuk menemukan jawaban dari pertanyaan- pertanyaan yang menjadi perhatian filsafat manusia, dikala tidak ada jawaban-jawaban yang mampu memuaskannya.

Sejak tumbuh dan berkembang, selalu terlintas dalam benak manusia berbagai pertanyaan yang membutuhkan jawaban, diantaranya pertanyaan tentang

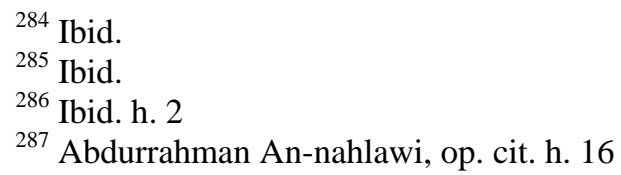

${ }^{287}$ Abdurrahman An-nahlawi, op. cit. h. 16 
ISTIGHNA, Vol. 1, No 1, Januari 2018 P-ISSN 1979-2824

Homepage: http://e-journal.stit-islamic-village.ac.id/index.php/istighna

Bach. Yunof Candra Problematika Pendidikan Agama Islam

darimana? Kemana? Untuk apa? Sungguh pun kesibukan hidup kadangkala menenggelamkan pertanyaan-pertanyaan ini, namun tetap saja suatu hari, pasti manusia akan bertanya kembali kepada dirinya sendiri dan hanya agama yang akan memberikan jawaban semuanya.

Sesuatu yang membuat menderita kehidupan manusia adalah jika manusia itu hidup dalam cengkraman keragu-raguan, kebingungan, kebimbangan atau hidup dalam gelapnya kebutaan dan kebodohan, khususnya dalam memahami hakikat dirinya sendiri, rahasia dari keberadaannya, tujuan akhir kehidupannya dan mati tanpa mengtahui tujuan hidupnya.

Manusia butuh jiwa yang sehat dan rohani yang kuat. Kebutuhan manusia terhadap tuntutan hidup, cita-cita dan kesengsaraan menuntut manusia juga harus memiliki tiang kuat yang akan menjadi sandaran baginya, kebutuhan kepada tempat bersandar yang kuat yang dapat dijadikan pegangan ketika dia merasakan berbagai penderitan, mengalami berbagai kesusahan dan kehilangan sesuatu yang di cintainya, atau menghadapi sesuatu yang dibencinya, tidak terwujud sesuatu yang diharapkannya, atau ketika manusia jatuh dalam keadaan yang sangat ditakutkannya. Disinilah agama akan datang dan memberikan kekuatan pada saat lemah, memberikan semangat baru pada saat hampir berputus asa, memberikan harapan baru pada saat ketakutan, dan memberikan kesabaran pada saat menderita, tersiksa atau putus asa. Sesungguhnya keyakinan terhadap Allah SWT akan memberikan kekuatan terhadap jiwa dan rohani setiap manusia.

Dalam menjalankan kehidupannya pun manusia butuh norma-norma atau aturan-aturan yang dapat membawa tiap-tiap individu manusia kepada perbuatan baik. Manusia juga butuh peraturan dan norma-norma yang dapat setiap orang berada pada rambu-rambu yang baik bagi dirinya, tidak merampas hak orang lain, atau merusak kepentingan bersama karena kepentikan pribadinya. Penekanan terhadap norma-norma dan peraturan agama adalah pada penerapan akhlak yang didasari atas keimanan karena tanpa akhlak tidak akan pernah ada undang-undang, norma-norma atupun aturan-aturan, dan tanpa iman tidak akan ada akhlak.

Apabila disimpulkan semua penjelasan tentang agama, maka akan didapatkan bahwa agama bukan hanya sekedar keyakinan dan ritual semata, tetapi 
ISTIGHNA, Vol. 1, No 1, Januari 2018 P-ISSN 1979-2824

Homepage: http://e-journal.stit-islamic-village.ac.id/index.php/istighna

Bach. Yunof Candra Problematika Pendidikan Agama Islam

agama juga merupakan hidup, kehidupan dan gaya hidup manusia. Bagimana manusia berpakaian, bagaimana manusia makan dan minim, bagaimana tidur yang sehat dan baik, bagaimana menjadi manusia yang baik, bagaimana berdagang yang baik dan masih banyak lagi, kesemua peraturan agama adalah kebaikan untuk kehidupan manusia. Itulah agama, tujuan, metode, cara, jalan hidup dan budaya Tuhan.

\section{Agama Islam}

Islam adalah bahasa Arab, dalam bahasa Arab Islam berasal dari kata aslama yang artinya menyerahkan diri, tunduk dan patuh. Asal usul kata aslama adalah berasal dari kata salima yang artinya selamat. Apabila arti kedua kata ini dihubungkan maka akan bermakna selamat bagi yang menyerahkan diri, tunduk dan patuh. Didalam Al-Quran kata Islam atau yang berhubungan dengan kata Islam terkadang dikaitkan dengan kata agama atau Ad-Diin, Al-Millah dan lain sebagainya. Seperti pada surat Ali Imran ayat kesembilan misalnya, Allah berfirman "sesungguhnya agama disisi Allah adalah Islam".

Menurut 'Abdurrahman An-Nahlawi dalam bukunya Usul At-Tarbiyyah AlIslamiyyah wa Asalibuha fil Bait wal Madrosah wal Mujtama' mendefinisikan Islam secara terminologi sebagai sebuah peraturan ilahi yang telah Allah sempurnakan dan menjadikannya peraturan yang sempurna, menyeluruh bagi segala segi kehidupan, dan meridoinya sebagai tata cara interaksi antara manusia dengan penciptanya, manusia dengan alam semesta, manusia dengan seluruh makhluk ciptaan, dengan dunia dan akhirat, dengan masyaraat, pasangan, anak, hakim, hukum dan dengan segala yang berkaitan dengan kehidupan manusia ${ }^{288}$.

Dari kedua definisi agama dan Islam apabila dihubungkan maka akan didapati makna bahwa agama Islam adalah agama yang mengatur cara hidup manusia yang sesuai dengan aturan undang-undang yang telah ditetapkan pencipta, yang memberikan keselamatan apabila mengikuti peraturan perundangundangan Tuhan dengan benar-benar menyerahkan diri, tunduk dan patuh, dan semua peraturan perundang-undangan sang pencipta ini benar-benar memberikan kebaikan, keselamatan bagi kehidupan ciptaannya. Seperti tatacara atau aturan

${ }^{288}$ Ibid. h. 17 
ISTIGHNA, Vol. 1, No 1, Januari 2018 P-ISSN 1979-2824

Homepage: http://e-journal.stit-islamic-village.ac.id/index.php/istighna

Bach. Yunof Candra Problematika Pendidikan Agama Islam

makan dan minum yang baik bagi kesehatan tubuh, cara makan dan minum yang baik dan sopan dihadapan manusia. Tata cara atau gaya hidup berpakaian yang baik bagi diri sendiri, terlihat sopan bagi orang lain, menyelamatkan dirinya dari segala bentuk kejahatan yang membahayakan. Dan masih banyak lagi peraturan perundang-undangan sang pencipta yang memberikan kebaiakan dan keselamatan bagi yang mengikutinya baik untuk dirinya sendiri atau untuk orang-orang disekitarnya. Inilah Islam, inilah agama Islam, agama yang sudah disempurnakan oleh sang pencipta dan agama, cara hidup, gaya hidup yang telah diridhoi sang pencipta sebagai satu-satunya agama, cara hidup, gaya hidup disisinya. Budaya Allah SWT.

\section{E. Pendidikan Agama Islam}

Pendidikan merupakan proses pembentukan manusia yang paripurna. Manusia dengan berbagai problem kehidupan yang dihadapi sangatlah membutuhkan pendidikan. Bahkan dalam Undang-Undang pun pemerintah menyatakan bahwa salah satu hak setiap warga Negara Kesatuan Republik Indonesia adalah mendapatkan pendidikan yang layak agar dapat mencerdaskan kehidupan Bangsa. Bukan hanya dalam Undang-Undang, dalam sistem pendidikan pun pemerintah ikut mengaturnya melalui kementrian pendidikan, ini memperjelas bahwa pendidikan adalah hal yang sangat penting bagi kehidupan setiap manusia untuk menjalankan kehidupannya baik pribadi, keluarga, masyarakat ataupun berbangsa.

Di sinilah peran pendidikan dituntut, bukan hanya terfokus pada pengembangan keterampilan-keterampilan dalam bidang teknologi dan ilmu pengetahuan saja, tetapi juga dituntut untuk membentuk watak dan kepribadian manusia yang baik agar dapat memahami hakikat sesungguhnya dari keterampilan-keterampilan yang dimilikinya. Banyak sekali disiplin ilmu yang menuntun dan mengembangkan keterampilan manusia tetapi yang menuntun, mengembangkan dan membantuk watak dan kepribadian hanya beberapa saja. Ini menunjukan bahwa ada ketidak seimbangan antara disiplin ilmu yang mengembangkan dan membentuk keterampilan manusia dan disiplin ilmu yang mengembangkan dan membentuk watak serta kepribadian manusia. Salah satu 
ISTIGHNA, Vol. 1, No 1, Januari 2018 P-ISSN 1979-2824

Homepage: http://e-journal.stit-islamic-village.ac.id/index.php/istighna

Bach. Yunof Candra Problematika Pendidikan Agama Islam

disiplin ilmu yang terfokus pada pengembangan dan pembentukan watak dan kepribadian adalah Pendidikan Agama Islam, dimana disiplin ilmu ini tidak hanya memberikan pengetahuan saja tetapi juga dituntut untuk mengamalkannya dalam kehidupan sehari-hari, mulai dari terbangun dari tidur sampai kembali tidur lagi, bahkan ketika tidur pun disiplin ilmu ini memberikan arahan dan tatacara yang baik.

Masih banyak sekali problematika dan permasalah-permasalahan dalam Pendidikan Agama Islam yang harus dicari solusinya, agar tujuan dari Pendidikan Agama Islam ini dapat tercapai dengan baik. Tantangan demi tantangan yang terus berkembang karena teknologi dan ilmu pengetahuan yang berkembang membuat Pendidikan Agama Islam harus lebih berkembang lagi agar bisa menjadi solusi untuk menghadapi semua tantangan perkembangan zaman. Para pelaku Pendidikan Agama Islam pun juga harus terus berusaha menggali dan mengembangan keilmuan ini lebih dalam lagi agar tujuannya sebagai penyempurna akhlak manusia bisa tercapai walaupun semakin banyak tantangantantangan yang berkembang seiring berkembangnya zaman serta ilmu pengetahuan dan teknologi.

\section{E. Problematika Pendidikan Agama Islam}

Problematika merupakan permasalahan-permasalahan, persoalan- persoalan atau kesenjangan-kesenjangan yang ada yang menjadi tantangan yang harus dicari solusinya. Menurut kamus bahasa Indonesia problematika merupakan hal yang menimbulkan masalah, hal yang belum dipecahkan, permasalahan.

Problematika merupakan halangan yang terjadi pada kelangsungan suatu proses atau masalah ${ }^{289}$.

Problematika Pendidikan Agama Islam adalah permasalahan- permasalahan, persoalan-persoalan, kesenjangan-kesenjangan yang menjadi halangan yang ada dalam sebuah proses Pendidikan Agama Islam baik sebagai sebuah disiplin ilmu, institusi ataupun jalan hidup, yang menjadi sebuah tantangan bagi setiap manusia muslim untuk mencari solusinya.

${ }^{289}$ Di akses dari http://eprints.walisongo.ac.id/1072/3/061211017_Bab2.pdf pada taggal 18 April 2016. 
ISTIGHNA, Vol. 1, No 1, Januari 2018 P-ISSN 1979-2824

Homepage: http://e-journal.stit-islamic-village.ac.id/index.php/istighna

Bach. Yunof Candra Problematika Pendidikan Agama Islam

Problematika Pendidikan Agama Islam tidak bisa terlepas dari ruang lingkup pendidikan itu sendiri. Ruang lingkup pendidikan ada tiga yaitu sekolah, rumah dan lingkungan. Disetiap ruang lingkup pendidikan pasti ada problematikanya masing-masing dan berpengaruh terhadap proses pendidikan diruang lingkup lainnya. Semua problematika di setiap runag lingkup harus dicari solusinya agar setip proses Pendidikan Agama Islam di setiap ruang lingkupnya bisa berjan maksiamal dan saling beriringan, apabila hanya satu ruang lingkup saja yang menjadi pembahasan dan dicari solusinya maka prosen Pendidikan Agama Islam di ruanng lingkup yang lain akan kurang maksimal. Ini semua adalah tugas setiap individu muslim khususnya yang berkecimpung di dunia Pendidikan Agama Islam baik di sebuah institusi ataupun dilingkungan masyarakatnya.

Berarti apabila dilihat dari aspek ruang lingkup pendidikan, problematika Pendidikan Agama Islam terbagi menjadi tiga, problematika Pendidikan Agama Islam di sekolah, problematika Pendidikan Agama Islam di rumah dan problematika Pendidikan Agama Islam di lingkungan masyarakat.

\section{F. Problematika Pendidikan Agama Islam di Sekolah}

1. Problematika peserta didik

Sebagian besar peserta didik masih beranggapan dan memandang bahwa Pendidikan Agama Islam hanya sebatas formalitas saja ${ }^{290}$. Hanya sebatas disiplin ilmu yang diajarkan untuk mendapatkan standar nilai yang ditentukan. Hanya sebatas ritual dan segi-segi formalitas dalam agama, seolah-olah apa yang disebut agama adalah seperangkat gerakan dan bacaan-bacaan serta doa-doa dalam ritual sembahyang dan ibadah. Dalam agama Islam ritual itu terumuskan dalam rukun Islam. Tentu saja pandangan seperti ini tidak salah secara mutlak tetapi jelas amat tidak memadai untuk menjadi pandangan yang baik, terutama terhadap Pendidikan Agama Islam.

Hal ini bukan berarti ritual agama Islam seperti sholat dan lain sebagainya tidak penting. Tetapi perlu disadari tindakan ritual agama seperti solat adalah salah satu wujud nilai aplikatif dari rasa iman, rasa percaya kita terhadap Allah

${ }^{290}$ Tim Pengembangan Ilmu Pendidikan FIP-UPI, Ilmu dan Aplikasi Pendidikan Bagian III : Pendidikan Disiplin Ilmu, Imtima, 2009, h. 6 
ISTIGHNA, Vol. 1, No 1, Januari 2018 P-ISSN 1979-2824

Homepage: http://e-journal.stit-islamic-village.ac.id/index.php/istighna

Bach. Yunof Candra Problematika Pendidikan Agama Islam

SWT dan juga kerangka bangunan agama Islam. Dengan demikian ritual agama seperti sholat bukanlah tujuan utama dari agama Islam tetapi bagaimana nilai-nilai dari solat itu teraplikasikan dalam kahidupan sehari-hari, seperti nilai ketundukan terhadap Allah SWT teraplikasi dalam wujud menjalankan segala perintahnya dan menjauhi segala larangannya. Nilai mengagungkannya teraplikasikan dalam sikap rendah hati, tidak sombong, tidak menentangnya, tidak meremehkan orang lain dan lain sebagainya. Nilai berserah diri kepadanya teraplikasikan dalam sikap sabar, tawakal dan sadar bahwa semua berjalan sesuai kehendaknya. Dan masih banyak lagi nilai-nilai lainnya yang apabila teraplikasikan dengan baik dalam kehidupan maka akan baiklah kehidupan ini karena sesuai dengan nilai-nilai yang ditetapkan oleh sang pencipta kehidupan.

Tindakan ritual dan segi-segi formalitas agama, baru mempunyai makna hakiki jika mampu mengantarkan seseorang kepada tujuannya yang hakiki pula, yaitu kedekatan kepada sang pencipta sehingga memiliki kesiapan emosional dan spiritual dalam menjalani kehidupannya di dunia dalam mencapai pengalaman transedental. Wujud kedekatan kepada sang pencipta itulah yang akan termanifestasikan dalam berbagai sikap dan prilaku yang terpuji (akhlaqul karimah), sehingga bisa memberi manfaat dan kebaikan terhadap semua.

Dengan demikian agama merupakan keseluruhan tingkah laku manusia dalam hidup dan kehidupan. Tingkah laku itu membentuk keutuhan manusia berakhlak mulia atas dasar percaya atau beriman kepada Tuhan dan tanggung jawab pribadi di hari kemudian. Pandangan seperti inilah yang harusnya menjadi arah pengajaran agama disekolah. Agar peserta didik paham betul tujuan yang paling utama dari Pendidikan Agama Islam. Dalam kasus keluarga terutama orang tua peserta didik, sekolah bisa mengadakan pertemuan baik setiap minggu ataupun setiap bulan untuk menyamakan visi dalam pendidikan disekolah dan dirumah, agar tercipta keserasian antara pendidikan disekolah dan dirumah terutama dalam Pendidikan Agama Islam.

2. Problematika pendidik

Para pakar pendidikan di Indonesia menilai bahwa salah satu sebab utama kegagalan pendidikan adalah karena lemahnya kualitas pendidik. Padahal salah 
ISTIGHNA, Vol. 1, No 1, Januari 2018 P-ISSN 1979-2824

Homepage: http://e-journal.stit-islamic-village.ac.id/index.php/istighna

Bach. Yunof Candra Problematika Pendidikan Agama Islam

satu syarat mutlak keberhasilan pendidikan adalah kualitas pendidik yang baik. Rasulullah adalah suri tauladan dan contoh pendidik yang baik terutama dalam Pendidikan Agama Islam. Karena itu semua pendidik muslim yang terlibat dalam Pendidikan Agama Islam baik sebagai sebuah disiplin ilmu, institusi ataupun jalan hidup haruslah menjadikan Rasulullah sebagai contoh dalam mendidik dan dalam menjalankan kesehariannya sebagai seoran pendidik agama Islam

Setidaknya minimal seorang pendidik harus memiliki empat kompetensi yaitu kompetensi pedagogik, kompetensi kepribadian, kompetensi profesional dan kompetensi sosial. Selain memiliki keempat kompetensi ini seorang pendidik juga harus mengembangkannya agar tidak monoton dalam mendidik para peserta didik. Seperti yang telah disabdakan Rasulullah bahwa hari ini harus lebih baik dari kemarin, dan besok harus lebih baik dari hari ini itulah perinsip setiap pendidik muslim. ${ }^{291}$

Jadi problematika pendidik agama Islam adalah belum meneladani Rasulullah secara totalitas, belum mengamalkan nilai ajaran-ajaran agama secara menyeluruh dimulai dari bangun tidur sampai tertidur lagi, belum mengembangkan potensi dirinya dengan baik. Kesemuanya ini haruslah beriringan tidak bisa apabila ingin menjalankan solusinya satu persatu. Semoga para pendidik agama Islam kita semakin baik dengan terus berusaha mengamalkan ajaran- ajaran agamanya secara maksimal dan mengembangkan potensi dirinya, agar tujuan uama dari Pendidikan Agama Islam sebagai penyempurna akhlak manusia dapat terwujud.

3. Problematika manajemen

Manajemen yang menaungi Pendidikan Agama Islam pun belum memberikan usahanya yang maksimal. Salah satu keberhasilan sebuah proses adalah karena terkendali dengan baik. Manajemen kurikulum dan pembelajaran belum memberikan ruang yang maksimal untuk Pendidikan Agama Islam. Ini bisa dilihat dari jumlah jam pelajaran yang diberikan untuk pembelajaran Pendidikan Agama Islam, dalam satu minggu hanya diberi empat jam pelajaran. Memberikan jam lebih untuk pembelajaran Pendidikan Agama Islam di atas empat jam belum

${ }^{291}$ Mulyasa, Standar Kompetensi dan Sertifikasi Guru, Rosada, Bandung, 2009, h. 4. 
ISTIGHNA, Vol. 1, No 1, Januari 2018 P-ISSN 1979-2824

Homepage: http://e-journal.stit-islamic-village.ac.id/index.php/istighna

Bach. Yunof Candra Problematika Pendidikan Agama Islam

memungkinkan, tetapi seandainya sekolah bisa mengatur lingkungan disekolah sebagai jam aplikasi Pendidikan Agama Islam maka ini bisa membantu kekurangan jam pembelajaran Pendidikan Agama Islam. Dengan membiasakan lingkungan sekolah untuk solat berjamaah misalnya atau melaksanakan kegiatankegiatan agama lainnya dalam lingkungan sekolah, ini akan memberikan pengaruh baik terhadap belajar peserta didik tentang Pendidikan Agama Islam.

Kurikulum yang dipakai di sekolah juga belum komperhensif masih terpaku pada teori-teori yang bersifat kognitif dan praktik amalan-amalan keagamaan sebatas ritual saja. Padahal seharusnya kurikulum Pendidikan Agama Islam dapat diaplikasikan dalam kehidupan nyata sehari-hari, karena agama bukan hanya sekedar keyakinan dan ritual saja tetapi agama adalah gaya hidup dan jalan hidup yang membentuk akhlak setiap manusia.

Manajemen sarana prasarana juga sangat dibutuhkan dalam membantu terealisasinya Pendidikan Agama Islam. Dimana setiap praktik keagamaan dalam segala bentuk aplikasinya sangat membutuhkan sarana yang memadai. Manajemen keuangan juga sangat berpengaruh terhadap perkembangan Pendidikan Agama Islam, terutama dalam sebuah institusi pendidikan. Diharapkan manajemen keuangan ini bisa membantu dan menopang semua kebutuhan pendidikan yang ada. Tetapi apabila hanya mengandalkan iuran peserta didik ataupun bantuan dana pemerintah maka proses pendidikan akan tersendat. Alangkah baiknya sebuah institusi pendidikan mengembangkan sektor keuangan melaluai pengembangan unit-unit usaha dan manajemen kewirausahaan pendidikan, agar berjalannya pendidikan bisa berjalan dengan baik, seiring berkembangnya keuangan maka proses pendidikan pun tidak akan terhambat.

Gaya komunikasi dalam manajeman pun haruslah sesuai dengan yang dicontohkan oleh suri tauladan para guru yaitu Rasulullah SAW. Bagaimana Rasul selalu menjadikan rekan-rekannya dalam perjuangan dakwah, perjuangan mendidik umat, perjuangan mendidik agama Islam sebagai sahabat. Bukan seperti atasan dan bawahan. Penyampaian pesan dalam manajemen diharapkan dapat memaksimalkan potensi peran-peran yang terlibat dalam kemajuan pendidikan terutama pendidikan. 
ISTIGHNA, Vol. 1, No 1, Januari 2018 P-ISSN 1979-2824

Homepage: http://e-journal.stit-islamic-village.ac.id/index.php/istighna

Bach. Yunof Candra Problematika Pendidikan Agama Islam

Problematika dalam manajemen diharapkan bisa mendapatkan solusi yang lebih baik terutama dalam pembentukan lingkungan sekolah dan bekerjasama dengan lingkungan tempat tinggal para pendidik. Karena apabila pendidik hanya dituntut untuk mengembangkan institusi pendidikan saja maka ketercapaian tujuan Pendidikan Agama Islam akan kurang maksimal. Pendidik bukan hanya mendidik peserta didik tetapi juga harus mendidik lingkungannya.

\section{G. Problematika Pendidikan Agama Islam di rumah}

Penerapan pendidikan dirumah sangat tergantung kepada para pemegang peran yang dominan yaitu orang tua yang didalam Al-Quran dikatakan sebagai penegak hukum Allah dalam lingkungan keluarga ${ }^{292}$, terutama ayah sebagai kepala rumah tangga. Sebagai pemegang kepeminpinan dalam keluarga seorang ayah haruslah dapat membentuk lingkungan keluarganya dengan baik, terutama dalam menerapkan nilai-nilai agama Islam, inilah yang dikatakan sebagai penegak hukum Allah. Apabila peran seorang ayah sudah maksimal dalam membentuk lingkuang keluarga yang baik maka sudah dapat dipastikan bahwa problematika Pendidikan Agama Islam dalam ruang lingkup keluarga akan dapat terselesaikan. Apalagi ada rekan yang membantunya yaitu ibu sebagai pendidik pertama bagi sang anak. Semakin sempurnalah apabila kedua individu ini bekerjasama dalam membentuk keluarga yang sakinah, mawaddah wa rahmah.

Tetapi dalam realitanya masih banyak orang tua yang kurang perduli dengan penerapan pendidikan agama anaknya dirumah karena mereka lupa peran mereka sebagai penegak hukum Allah. Masih ada orang tua yang lebih mementingkan nilai kognitif anak dalam bidang disiplin ilmu eksak dibanding penerapan niainilai agama. Padahal apabila dikaji lebih dalam peran utama orang tua dirumah adalah pembentukan kepribadian dan akhlak yang baik bagi anak. Sebagaimana firman Allah "jagalah dirimu dan keluargamu dari api neraka". Pada firman Allah ini jelas bahwa pendidikan akhlak adalah yang paling utama dirumah. Dan tidak ada akhlak tanpa pendidikan agama yang baik. Penerapan nilai-nilai agama dalam membentuk akhlak dirumah dapat mempengaruhi kenyamanan anak pada tempat tinggalnya dan dapat sangat membantu pendidikan anak disekolah, baik

${ }^{292}$ Abdurrahman An-nahlawi, op. cit. h. 122 
ISTIGHNA, Vol. 1, No 1, Januari 2018 P-ISSN 1979-2824

Homepage: http://e-journal.stit-islamic-village.ac.id/index.php/istighna

Bach. Yunof Candra Problematika Pendidikan Agama Islam

pendidikan agamanya maupun pendidikan eksaknya, karena anak sudah dibekali dengan akhlak yang baik sehingga ia akan menghadapi segala sesuatu dengan akhlak dan sikap yang baik. Selain itu orang tua juga harus lebih sering berkomunikasi dengan pihak institusi pendidikan agar terjalin hubungan dan tercapai tujuan pendidikan yang jelas yang ingin dicapai bersama.

Pelaku pendidikan di rumah juga harus perduli dengan pembentukan lingkungan Pendidikan Agama Islam di lingkungan masyaraktnya. Karena anaknya adalah bagian dari masyarakat disekitarnya. Apabila baik lingkuang bermain anak didalam masyarakat dan keluarga maka perkembangan pendidikan agama Islamnya pun akan baik.

Apabila disimpulkan secara ringkas maka peran orang tua dalam membentuk lingkugan keluarga yang baik dirumah adalah sebagai penegak hukum Allah, sebagai pencipta rasa aman dan nyaman khususnya dilingkungan keluarga, sebagai pembentuk generasi yang soleh, dan sebagai pendidik pertama bagi anak-anaknya

\section{H. Problematika Pendidikan di Lingkungan}

Peran mendidik adalah peran setiap manusia, karena mendidik dan dididik adalah tugas dan fitrah setiap manusia. Hal ini bisa dilihat dari apa yang telah disabdakan oleh Rasulullah SAW bawa "menuntut ilmu wajib bagi setiap muslim dan muslimah”. Perintah mendidik juga difirmankan Allah dalam surat al-'Ashr "saling menasehatilah dalam kebenaran dan saling menasehatilah dalam kesabaran". Hanya manusialah makhluk berpendidikan. Ini menunjukan bahwa peran mendidik bukan hanya milik guru, dosen, ustadz dan pendidik-pendidik lainnya saja, tetapi tugas mendidik adalah tugas setiap manusia. Terutama dalam Pendidikan Agama Islam. Dalam masyarakat Pendidikan Agama Islam bukanlah sebuah disiplin ilmu ataupun institusi belaka, tetapi Pendidikan Agama Islam adalah pendidikan jalan hidup untuk mengarungi kehidupan dunia dan menggapai kebahagiaan di kehidupan akhirat.

Keberhasilan pendidikan agama adalah merupakan tanggung jawab bersama antara pemerintah, keluarga dan masyarakat. Dalam undang-undang tentang pendidikan, terdapat perbedaan definisi istilah pendidikan agama pendidikan 
ISTIGHNA, Vol. 1, No 1, Januari 2018 P-ISSN 1979-2824

Homepage: http://e-journal.stit-islamic-village.ac.id/index.php/istighna

Bach. Yunof Candra Problematika Pendidikan Agama Islam

keagamaan. Posisi pendidikan Islam di dalam undang- undang cukup strategi dan kuat. Hal ini dapat dilihat antara lain: ${ }^{293}$

1. Pasal 30 (1) Undang-Undang RI Nomor 20 Tahun 2003 tentang system pendidikan nasional (Sisdiknas) dikatakan bahwa "pendidikan keagamaan diselenggarakan oleh pemerintah dan/atau kelompok masyarakat dari pemeluk agama sesuai dengan peraturan perundang- undangan.” [UU RI No.20/ 2003, pasal 30 (1)]. Pasal ini menunjukkan legalitas eksistensi pendidikan agama Islam adalah kuat dan dijamin oleh konstitusi negara.

2. Pendidikan keagamaan berfungsi "mempersiapkan peserta didik menjadi anggota masyarakat memahami dan mengamalkan nilai- nilai ajaran agamanya dan / atau menjadi ahli ilmu agama.” (UU RI No. 20/ 2003, pasal 30 ayat 2 ).

3. Pendidikan keagamaan "dapat dilaksanakan pada jalur pendidikan formal, non formal dan informal." [UU RI No. 20 / 2003, pasal 30(3)].

Penerapan Pendidikan Agama Islam dalam masyarakat adalah tanggung jawab seluruh masyarakat khususnya para tokoh masyarakat dan tokoh agama. Masjid sebagai pusat penerapan Pendidikan Agama Islam harus dimanfaatkan semaksimal mungkin. ${ }^{294}$ Apabila penerapan agama Islam berjalan dengan maksimal ditenagah-tengah masyarakat, baik dilingkuan masyarakat tinggal maupun di lingkungan perpolitikan negara atau lingkungan pemerintah, pastilah akan memberikan rasa aman, nyaman, damai dan tentram dalam setiap individu masyarakat. Karena semua individu masyarakat melaksanakan ajaran agamanya dengan baik, terutama agama Islam dalam kehidupan sehari-hari.

${ }^{293}$ Nurfitriyani, Problematika Pendidikan Agama Islam di Sekolah, diakses dari https://nurfitriyani49.wordpress.com/2013/09/10/problematika-pendidikan-agamaislam-disekolah/ pada tanggal 18 April 2016.

${ }^{294}$ Abdurrahman An-nahlawi, op. cit. h. 131 


\begin{tabular}{|c|c|c|}
\hline $\begin{array}{c}\text { Ruang } \\
\text { Lingkup }\end{array}$ & Problem & Solusi \\
\hline \multirow[t]{3}{*}{ Sekolah } & $\begin{array}{l}\text { 1. Peserta Didik PAI } \\
\text { Hanya formalitas nilai } \\
\text { pelajaran, ritual ibadah dan } \\
\text { doa-doa. }\end{array}$ & $\begin{array}{l}\text { Mengajarkan penerapan nilai- } \\
\text { nilai praktik agama dalam } \\
\text { kehidupan sehari- hari dan } \\
\text { menekankan nilai- nilai agama } \\
\text { dalam setiap kegiatan yang } \\
\text { dilakukan, bekerjasama dengan } \\
\text { pihak keluarga dirumah dan } \\
\text { lingkungan masyarakat. }\end{array}$ \\
\hline & $\begin{array}{l}\text { 2. Kualitas pendidik yang } \\
\text { kurang maksimal }\end{array}$ & $\begin{array}{l}\text { Meningkatkan kualitas diri } \\
\text { dengan terus mengembangkan } \\
\text { potensi yang dimiliki dengan } \\
\text { cara berperan serta dalam setiap } \\
\text { pengembangan dan penerapan } \\
\text { praktik agama di lingkungan } \\
\text { masyarakat sehingga benar- } \\
\text { benar bisa menjadi pendidik } \\
\text { yang sebenarnya, meneladani } \\
\text { Rasulullah SAW. }\end{array}$ \\
\hline & 3. Manajemen kurikulum & $\begin{array}{l}\text { Membentuk lingkungan sekolah } \\
\text { yang benar-benar menerapkan } \\
\text { nilai-nilai Islam dalam setiap } \\
\text { kegiatannya dengan dukungan } \\
\text { sarana prasarana yang memadai } \\
\text { yang ditopang dengan kekuatan } \\
\text { ekonomi yang baik. }\end{array}$ \\
\hline
\end{tabular}


ISTIGHNA, Vol. 1, No 1, Januari 2018 P-ISSN 1979-2824

Homepage: http://e-journal.stit-islamic-village.ac.id/index.php/istighna

Bach. Yunof Candra Problematika Pendidikan Agama Islam

\begin{tabular}{|c|c|c|}
\hline Keluarga & $\begin{array}{l}\text { Penerapan ajaran agama } \\
\text { yang masih kurang } \\
\text { maksimal }\end{array}$ & $\begin{array}{l}\text { Menjalin komunikasi yang baik } \\
\text { dengan sekolah dan lingkungan } \\
\text { masyarakat terutama dalam } \\
\text { penerapan- penerapan praktik } \\
\text { nilai-nilai agama Islam }\end{array}$ \\
\hline Masyarakat & $\begin{array}{l}\text { Kurangnya kesadaran } \\
\text { menjalankan ajaran agama } \\
\text { dan peran setiap individu } \\
\text { dengan baik }\end{array}$ & $\begin{array}{l}\text { Masjid sebagai } \\
\text { pendidikan meberikan kajian- } \\
\text { kajian tentang ajaran agama, } \\
\text { peran dan tanggung jawab } \\
\text { manusia yang harus saling } \\
\text { menasehati dalam kebaikan dan } \\
\text { kesabaran. }\end{array}$ \\
\hline
\end{tabular}

\section{Penutup}

Peran mendidik merupakan peran setiap manusia. Terutama dalam melestarikan budaya Tuhan di muka bumi ini yaitu ajaran agama. Setiap manusia haruslah menjadi pendidik agama dalam kehidupannya. Minimal dengan menjalankan ajaran agama dengan baik di lingkungan tempat tinggalnya. Begitu pula dengan penerapan pendidikan agama dirumah. Ini menjadi tanggung jawab orang tua. Diharapkan orang tua perduli dengan kegiatan pendidikan agama dirumah khususnya sholat lima waktu.

Dalam institusi pendidikan pun harus dilakukan pembenahan. Baik dari sisi pendidik atau pun menejemen pendidikannya. Setiap pendidik agama Islam haruslah benar-benar menguasai ajaran agamanya dan metode-metode dalam mengajarkannya. Dan diharapkan pendidik juga mau mengembangkan kompetensi dirinya agar lebih baik lagi. Manajemen sekolah juga diharapkan melakukan pembenahan-pembenahan, baik dibidang keuangan, sarana prasarana, komunikasi, kurikulum ataupun lingkungan belajar disekolah. Apabila kesemua ini bisa menerapkan setiap solusi dari tantangan-tangtangan yang ada maka Pendidikan Agama Islam akan lebih berkembang dan terciptalah masyarakat yang baik sesuai dengan budaya yang sang pencipta inginkan. 
ISTIGHNA, Vol. 1, No 1, Januari 2018 P-ISSN 1979-2824

Homepage: http://e-journal.stit-islamic-village.ac.id/index.php/istighna

Bach. Yunof Candra Problematika Pendidikan Agama Islam

\section{DAFTAR PUSTAKA}

An-nahlawi, Abdurrahman, Ushul At-Tarbiyah Al-Islamiyyah Wa Asalibaha Fil Bait Wal Madrosah Wal Mujtama', (Damaskus: Darul Fkri, 1979)

Al-Qordhowi, Yusuf, Sistem Pengetahuan Islam, Terj. (Jakarta: Restu Ilahi, 2004)

Tim Pengembangan Ilmu Pendidikan FIP-UPI, Ilmu dan Aplikasi Pendidikan Bagian 1: Ilmu Pendidikan Teoritis, (t.k.: PT. IMTIMA, 2009)

-, Ilmu dan Aplikasi Pendidikan Bagian 3 : Pendidikan Disiplin Ilmu, (PT. IMTIMA, 2009)

Sa'ud, Udin Syaefudin dan Abin Syamsuddin Makmun, Perencanaan Pendidikan, (Bandung: Rosada, 2009)

Mulyasa, Standar Kompetensi dan Sertifikasi Guru, (Bandung: Rosada, 2009) Rohiat, Manajemen Sekolah, Teori Dasar dan Peraktik, (Bandung: Refika Aditama, 2010)

Tim Pakar Manajemen Pendidikan Universitas Negeri Malang, Manajemen Pendidikan Analisis Subtansi dan Aplikasinya Dalam Istitusi Pendidikaan, (Malang: Universitas Negeri Malang, 2003)

Nurfitriyani, Problematika Pendidikan Agama Islam di Sekolah, diakses dari https://nurfitriyani49.wordpress.com/2013/09/10/problematika- pendidikanagama-Islam-di-sekolah/ pada tanggal 18 April 2016

http://eprints.walisongo.ac.id/1072/3/061211017_Bab2.pdf diakses pada taggal 18 April 2016. 